\title{
Beberapa Faktor yang Berhubungan dengan Kejadian HIV/AIDS pada Wanita (Studi Kasus di Kabupaten Kendal)
}

\author{
Siti Musyarofah",Suharyo Hadisaputro ",Budi Laksono ${ }^{* * *}$, Muchlis A.U. Sofro ${ }^{* * * *}$, Lintang Dian S ${ }^{* * * * *}$ \\ "Sekolah Tinggi Ilmu Kesehatan Kendal," Politeknik Kesehatan Semarang, ${ }^{* * *}$ Dinas Kesehatan Provinsi \\ Jawa Tengah, ${ }^{* * * *}$ RSUD Dr. Kariadi Semarang, \\ Fakultas Kesehatan Masyarakat Universitas Diponegoro
}

\begin{abstract}
Background: HIV/AIDS are major problem that threatens Indonesia and many countries around the world. In 2011 there were 17.3 million adults living with AIDS were women. The purpose of studies proved that host and environmental factors were associated the occurence of HIV/AIDS in women.

Method: The research using case-control study, was supported by indepth interview. The target population were women in Kendal with a sample of 76 women consisted of 38 women with HIV/AIDS and 38 women negative HIV. Samples case with consecutive sampling technique, control with cluster sampling. Bivariate analysis using chi-square test and multivariate analysis used logistic regression.

Results: Multivariate analysis showed that host factors significantly associated with the occurence of HIV/AIDS in women were the number of sexual partners more than $1(\mathrm{p}=0,003)$, level of education was low $\leq 9$ years $(p=0,049)$ and the first married age $<20$ years $(p=0,03)$; environment factors significantly associated was history of HIV/AIDS on her husband $(\mathrm{p}=$ 0,001). Host factors were not significantly associated with the occurence of HIV/AIDS in women were history of receiving blood donors, history of sexually transmitted diseases, the status of drug users, the habit of drinking alcohol, violence, type of job, and socioeconomic.

Conclusion: Host factors significantly associated with the occurence of HIV/AIDS in women were the number of sexual partners more than 1 , level of education was low $\leq 9$ years, and the first married age $<20$ years; environment factors significantly associated was history of HIV/AIDS on her husband.
\end{abstract}

Keywords: HIV/AIDS; Women; Associated Factors

*Penulis korespondensi : sitimusyarofah24@gmail.com 


\section{Pendahuluan}

AIDS (Acquired Immuno Deficiency Syndrome) adalah penyakit yang perlahanlahan menurunkan sistem kekebalan tubuh. Orang dengan AIDS tidak dapat melawan kuman dan kanker. HIV (Human Immunodeficiency Virus) adalah virus penyebab AIDS. Virus ini akan merusak limfosit T CD4, atau sel T. Sel T mengganggu sistem kekebalan tubuh, dan tubuh menjadi lebih rentan terhadap penyakit lainl ${ }^{2}$.

HIV/AIDS adalah masalah besar yang mengancam seluruh dunia. HIV/AIDS menyebabkan berbagai krisis secara bersamaan, krisis kesehatan, krisis pembangunan negara, krisis ekonomi, pendidikan dan juga krisis kemanusiaan3. Dalam Millenium Development Goals $\left(M D G^{\prime} s\right)$ di antaranya adalah menekan kasus AIDS, meningkatkan kesehatan ibu, dan mengurangi angka kematian anak4.

5Pada tahun 2011 terdapat 17,3 juta dari 38,6 juta orang dewasa yang hidup dengan AIDS adalah wanita. Angka tersebut telah meningkat di setiap daerah di dunia selama masa dua tahun terakhir6. Laporan epidemik tahun 2013 secara global menunjukkan bahwa semua orang yang hidup dengan HIV di negara berpenghasilan rendah dan menengah $52 \%$ pada wanita7. Saat ini satu dari enam kematian anak berhubungan dengan AIDS di seluruh dunia dan satu dari tujuh infeksi baru HIV, sebagian besar melalui transmisi dari ibu ke anak6.

Beberapa faktor risiko meningkatkan kemungkinan wanita untuk tertular HIV yaitu faktor biologis, sosial, ekonomi, dan lingkungan. 2001 sebesar $0,1 / 100.000$ penduduk, tahun 2011 sebesar 6/100.000 penduduk8. Proyeksi kecenderungan epidemi HIV ke depan di Indonesia diperkirakan akan terjadi peningkatan jumlah infeksi baru HIV pada wanita9. Prevalensi HIV dan AIDS tahun 2014 (Juni) yaitu $60,15 / 100.000$ penduduk dan 23,41/100.000 penduduk. Prosentase AIDS pada wanita mengalami peningkatan tiap tahun dari tahun 1987 s/d 2014 (Juni) 10. Case Fatality Rate (CFR) AIDS sebesar $17,55 \%$ dan pada wanita $25,61 \% 10$.

Jawa Tengah peringkat ke 6 kasus HIV dan AIDS 10. Kasus baru HIV di Jawa Tengah cenderung meningkat dari tahun 2005 s/d 2013, sedangkan kasus baru AIDS selalu mengalami peningkatan tiap tahun pada periode tersebutl1. Prevalensi HIV dan AIDS tahun 2014 (Juni) sebesar $25,84 / 100.000$ penduduk dan $11,63 / 100.000$ penduduk. CFR sebesar 29,49\%10. Distribusi kasus AIDS lebih banyak pada wanita yaitu $61,4 \% 11$.

Kendal peringkat ke 10 kasus HIV/AIDS terbesar secara kumulatif di Jawa Tengah (Juni 2014)11. Jumlah kumulatif HIV/AIDS sejak tahun 2000 s/d 2014 (Juli) yaitu 396 kasus, terdiri dari 258 HIV dan 138 AIDS. Sebaran usia kasus HIV/AIDS paling banyak pada kelompok usia 25-49 tahun. CFR AIDS sebesar 30,30\%. Proporsi pada wanita sebesar HIV 73\% (188) dan AIDS $52 \%$ (72). Prevalensi HIV dan AIDS di Kabupaten Kendal sebesar 26,99/100.000 penduduk dan 14,44/100.000 penduduk. Sedangkan prevalensi HIV dan AIDS pada wanita di Kabupaten Kendal sebesar $39,81 / 100.000$ penduduk dan $15,25 / 100.000$ penduduk12.

Tujuan dari penelitian ini adalah untuk membuktikan faktor host dan faktor environment berhubungan dengan kejadian HIV/AIDS pada wanita.

\section{Metode}

Jenis desain penelitian yang digunakan adalah observasional dengan desain studi kasus kontrol, dan ditunjang dengan kajian kualitatif dengan wawancara mendalam/indepth interview. Populasi target (reference) dan populasi terjangkau (sumber) adalah seluruh wanita berusia 15 tahun ke atas yang ada di wilayah Kabupaten Kendal. Populasi kasus adalah seluruh wanita penderita HIV/AIDS di wilayah kerja dinas kesehatan Kabupaten Kendal, dan populasi kontrol adalah seluruh wanita bukan penderita HIV/AIDS di wilayah kerja dinas kesehatan Kabupaten Kendal.

Sampel kasus dan kontrol ditentukan dengan kriteria inklusi dan eksklusi. Sampel kasus adalah wanita penderita HIV/AIDS di wilayah kerja dinas kesehatan Kabupaten Kendal. Kriteria inklusi utama yaitu telah 
didiagnosis menderita HIV/AIDS dari hasil pemeriksaan rapid test dan tercatat di Dinas Kesehatan Kabupaten Kendal. Sampel kontrol adalah wanita bukan penderita HIV/AIDS di wilayah kerja dinas kesehatan Kabupaten Kendal. Kriteria inklusi utama yaitu telah diperiksa rapid test dan dinyatakan tidak menderita HIV/AIDS di layanan VCT Kabupaten Kendal. Kriteria inklusi antara kasus dan kontrol yang sama yaitu bersedia menjadi responden dan dapat berkomunikasi. Sedangkan kriteria eksklusi antara kasus dan kontrol sama yaitu pindah dari Kabupaten Kendal atau meninggal dan anita Pekerja Seks (WPS) yang tercatat di Dinas Kesehatan Kabupaten Kendal. Jumlah sampel baik kasus maupun kontrol masing -masing 38 responden.

Teknik pengambilan sampel kasus dengan consequtive sampling sedangkan sampel kontrol dengan cluster sampling. Consequtive sampling digunakan oleh karena keterbatasan jumlah sampel yang memenuhi kriteria.

Pengumpulan data primer melalui wawancara dengan menggunakan kuesioner dan panduan wawancara, sedangkan data sekunder diambil dari dinas kesehatan Kabupaten Kendal, layanan VCT di Kabupaten Kendal dan rekam medis Rumah Sakit tempat responden berobat. Analisis data secara bivariat menggunakan uji chisquare dan analisis multivariat menggunakan uji regresi logistik.

\section{Hasil}

Kabupaten Kendal merupakan salah satu kabupaten di Provinsi Jawa Tengah yang terletak di jalur utama Pantai Utara Pulau Jawa (Pantura). Secara umum wilayah Kabupaten Kendal menjadi 2 (dua) daerah dataran, yaitu dataran rendah (pantai) dan daerah dataran tinggi (pegunungan)13.
Kendal merupakan daerah rawan penularan HIV/AIDS. ${ }^{14}$ Daerah di sepanjang jalur pantai utara (Pantura) terus mendominasi dalam setiap temuan kasus baru HIV. Saat ini tidak terlepas dari posisi jalur tersebut yang menjadi pusat mobilisasi perekonomian. Sejumlah lokalisasi muncul di kawasan tersebut, seperti Gambilangu dan Alaska (Alas Karet). ${ }^{15}$

\section{Analisis Bivariat}

Berdasarkan analisis bivariat untuk melihat menunjukkan bahwa terdapat 8 variabel yang berhubungan dengan kejadian HIV/AIDS pada wanita. Tabel 1 berikut merupakan rangkuman hasil analisis bivariat dan yang dicetak tebal merupakan faktor yang berhubungan dengan kejadian HIV/AIDS pada wanita pada analisis bivariat.

Variabel riwayat menderita penyakit menular seksual tidak ada hasil analisis oleh karena $100 \%$ tidak ada riwayat menderita penyakit menular seksual baik pada kelompok kasus maupun kontrol. Kriteria penilaian dalam pemilihan variabel penting yang dipakai untuk memasukkan variabel bebas ke dalam analisis multivariat dengan memperhitungkan nilai $p<0,25$. Variabel yang memenuhi kriteria untuk dimasukkan dalam analisis multivariat sebanyak 9 variabel sebagaimana pada Tabel 2 .

Kita dapat memprediksi wanita yang suaminya ada riwayat HIV/AIDS, jumlah pasangan $>1$, tingkat pendidikan rendah $(\leq 9$ tahun), dan usia pertama menikah $<20$ tahun memiliki probabilitas untuk mengalami kejadian HIV/AIDS sebesar 5,49\%. 
Tabel 1. Rangkuman hasil analisis bivariat dengan kejadian HIV/AIDS pada wanita

\begin{tabular}{lllllllll}
\hline \multirow{2}{*}{ No. } & \multirow{2}{*}{ Variabel } & \multicolumn{2}{c}{ Kasus } & \multicolumn{2}{c}{ Kontrol } & \multirow{2}{*}{ OR } & $95 \% \mathrm{CI}$ & $\mathrm{p}$ \\
\cline { 3 - 6 } & & $\mathrm{n}$ & $\%$ & $\mathrm{n}$ & $\%$ & & & \\
\hline
\end{tabular}

1. Usia pertama menikah

$\begin{array}{llllllll}<20 \text { tahun } & 21 & 55,3 & 11 & 28,9 & 3,032 & 1,174-7,831 & 0,020 \\ \geq 20 \text { tahun } & 17 & 44,7 & 27 & 71,1 & & & \end{array}$

2. Tingkat pendidikan

$\begin{array}{lrrrrrrr}\text { Rendah }(\leq 9 \text { tahun }) & 34 & 89,5 & 25 & 65,8 & 4,420 & 1,287-15,181 & 0,013 \\ \text { Tinggi ( }>9 \text { tahun }) & 4 & 10,5 & 13 & 34,2 & & & \end{array}$

3. Riwayat transfusi darah

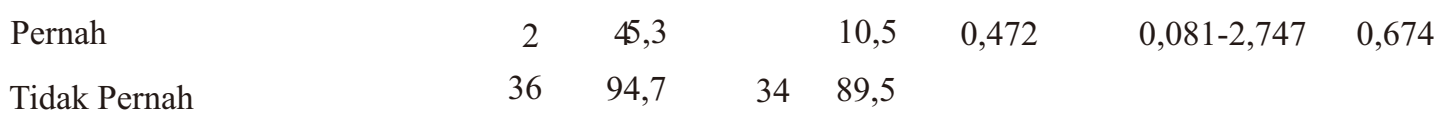

4. Riwayat menderita penyakit menular seksual (PMS)

5. Jumlah pasangan seksual

$\begin{array}{lrrrrrrr}>1 & 16 & 42,1 & 3 & 7,9 & 8,485 & 2,214-32,517 & 0,001 \\ 1 & 22 & 57,9 & 35 & 92,1 & & & \end{array}$

6. Status pengguna narkoba

$\begin{array}{lrrrrrrr}\text { Ya } & 2 & 5,3 & 1 & 2,6 & 2,056 & 0,178-23,676 & 1,000 \\ \text { Tidak } & 36 & 94,7 & 37 & 97,4 & & & \end{array}$

7. Kebiasaan minum alkohol

$\begin{array}{lrrrrrrr}\text { Ya } & 3 & 7,9 & 1 & 2,6 & 3,171 & 0,315-31,946 & 0,615 \\ \text { Tidak } & 35 & 92,1 & 37 & 97,4 & & & \end{array}$

8. Kekerasan

$\begin{array}{lrrrrrrr}\text { Ya } & 11 & 28,9 & 2 & 5,3 & 7,333 & 1,500-35,857 & 0,006 \\ \text { Tidak } & 27 & 71,1 & 36 & 94,7 & & & \end{array}$

9. Jenis pekerjaan

$\begin{array}{llllllll}\text { Berisiko } & 23 & 60,5 & 16 & 42,1 & 2,108 & 0,844-5,266 & 0,108 \\ \text { Tidak Berisiko } & 15 & 39,5 & 22 & 57,9 & & & \end{array}$

10. Riwayat HIV/AIDS pada suami

$\begin{array}{lrrrrrrr}\text { Ya } & 17 & 44,7 & 1 & 2,6 & 29,952 & 3,717-241,357 & 0,001 \\ \text { Tidak } & 21 & 55,3 & 37 & 97,4 & & & \end{array}$

11. Status penggunaan kondom pada pasangan

$\begin{array}{lrrrrrrr}\text { Ya } & 36 & 94,7 & 37 & 97,4 & 0,486 & 0,042-5,603 & 1,000 \\ \text { Tidak } & 2 & 5,3 & 1 & 2,6 & & & \end{array}$

12. Sosial ekonomi

\begin{tabular}{|c|c|c|c|c|c|c|}
\hline Rendah (Pendapatan< UMR) & 26 & 68,4 & & 31,6 & 4,694 & $1,784-12,351$ \\
\hline Cukup (Pendapatan $>=$ UMR) & 12 & 31,6 & 26 & 68,4 & & \\
\hline
\end{tabular}




\begin{tabular}{|c|c|c|c|c|c|c|c|c|}
\hline \multirow{2}{*}{ No. } & \multirow{2}{*}{ Variabel } & \multicolumn{2}{|c|}{ Kasus } & \multicolumn{2}{|c|}{ Kontrol } & \multirow{2}{*}{ OR } & \multirow{2}{*}{$95 \% \mathrm{CI}$} & \multirow{2}{*}{$\mathrm{p}$} \\
\hline & & $\mathrm{n}$ & $\%$ & $\mathrm{n}$ & $\%$ & & & \\
\hline \multicolumn{9}{|c|}{ 13. Peran suami } \\
\hline & Berisiko & 25 & 65,8 & 15 & 39,5 & 2,949 & $1,159-7,503$ & 0,022 \\
\hline & Tidak Berisiko & 13 & 34,2 & 23 & 60,5 & & & \\
\hline \multicolumn{9}{|c|}{ 14. Peran gender tradisional } \\
\hline & Ada & 21 & 55,3 & 31 & 81,6 & 0,279 & $0,099-0,789$ & 0,014 \\
\hline & Tidak Ada & 17 & 44,7 & 7 & 18,4 & & & \\
\hline
\end{tabular}

Tabel 2. Variabel penting (variabel kandidat) untuk analisis regresi logistik

\begin{tabular}{clrrr}
\hline No. & \multicolumn{1}{c}{ Variabel Penelitian } & \multicolumn{1}{c}{$\mathrm{p}$} & \multicolumn{1}{c}{ OR } & \multicolumn{1}{c}{ 95\%CI } \\
\hline 1. & Riwayat HIV/AIDS pada suami $(+)$ & 0,0001 & 29,952 & $3,717-241,357$ \\
2. & Jumlah pasangan seksual $>1$ & 0,001 & 8,485 & $2,214-32,517$ \\
3. & Sosioekonomi rendah (pendapatan $<$ UMR) & 0,001 & 4,694 & $1,784-12,351$ \\
4. & Kekerasan (+) & 0,006 & 7,333 & $1,500-35,857$ \\
5. & Tingkat pendidikan rendah ( $\leq 9$ tahun) & 0,013 & 4,420 & $1,287-15,181$ \\
6. Peran gender tradisional (+) & 0,014 & 0,279 & $0,099-0,789$ \\
7. Usia pertama menikah $<20$ tahun & 0,020 & 3,032 & $1,174-7,831$ \\
8. & Peran suami berisiko & 0,022 & 2,949 & $1,159-7,503$ \\
9. Jenis pekerjaan berisiko & 0,108 & - & - \\
\hline
\end{tabular}

Tabel 3. Variabel model akhir dengan analisis regresi logistik

\begin{tabular}{llrrrrr}
\hline No. & Variabel Independent & B & Wald & P & OR & \multicolumn{1}{c}{$95 \%$ CI } \\
\hline 1. & Riwayat HIV/AIDS pada suami $(+)$ & 4,428 & 11,839 & 0,001 & 83,746 & $6,723-1.043$ \\
\hline 2. & Jumlah pasangan seksual $>1$ & 3,149 & 8,968 & 0,003 & 23,321 & $2,969-183,187$ \\
\hline 3. & Tingkat pendidikan rendah $(\leq 9$ tahun $)$ & 2,709 & 3,874 & 0,049 & 15,011 & $1,011-222,772$ \\
\hline 4. & Usia pertama menikah $<20$ tahun & 1,727 & 4,729 & 0,03 & 5,624 & $1,186-26,672$ \\
\hline \multicolumn{6}{c}{ Konstanta } & $-8,961$ \\
\hline
\end{tabular}

Persamaan analisis multivariatnya adalah:

$$
\begin{aligned}
\mathrm{p} & =\frac{1}{1+\mathrm{e}^{-\mathrm{y}}} \\
& =\frac{1}{1+2,7182828^{-(3,052)}}
\end{aligned}
$$

Keterangan:

$\mathrm{p}=$ probabilitas untuk terjadinya suatu kejadian

$\mathrm{e}=$ bilangan natural, nilainya 2,718281828
Kita dapat memprediksi wanita yang suaminya ada riwayat HIV/AIDS, jumlah pasangan $>1$, tingkat pendidikan rendah $(\leq 9$ tahun), dan usia pertama menikah $<20$ tahun memiliki probabilitas untuk mengalami kejadian HIV/AIDS sebesar 95,49\%. 


\section{Pembahasan}

\section{Faktor yang Terbukti Berhubungan dengan Kejadian HIV/AIDS pada Wanita}

\section{Riwayat HIV/AIDS pada Suami}

Berdasarkan hasil analisis bivariat dan multivariat menunjukkan bahwa variabel riwayat HIV/AIDS pada suami memiliki hubungan yang signifikan dan merupakan faktor risiko kejadian HIV/AIDS pada wanita. Hasil analisis multivariat $p=0,001 ; \mathrm{OR}=83,746 ; 95 \% \mathrm{CI}=6,723-1.043$. Artinya wanita yang suaminya ada riwayat HIV/AIDS memiliki risiko terjadi HIV/ AIDS 83,746 kali lebih besar dibanding wanita yang suaminya tidak ada riwayat HIV/AIDS. Akan tetapi dari hasil analisis multivariat tersebut menunjukkan interval kepercayaannya (Confidence Interval) lebar. Lebarnya interval kepercayaan dikarenakan jumlah sampel yang minimal. Interval kepercayaan pada analisis bivariat 3,717241, 357 sehingga lebih sempit dibandingkan pada hasil analisis multivariat. Untuk mempersempit interval kepercayaan, maka perlu ditambah besar sampel penelitian. Proporsi suami yang belum dites $77,78 \%$ karena sudah meninggal terlebih dulu. Jadi kemungkinan suami ada riwayat HIV/AIDS pada kelompok kasus lebih besar dari 44,7\%.

Salah satu jalur utama penularan HIV/AIDS adalah melalui seks yang tidak aman dengan pasangan yang terinfeksi HIV16. Seks berisiko adalah hubungan seks yang berisiko penularan penyakit atau kehamilan yang tidak direncanakan17. Laporan Badan AIDS PBB atau UNAIDS, yang menyebutkan lebih dari 1,7 juta perempuan di ASIA hidup dengan HIV positif, dan $90 \%$ nya tertular dari suami atau pasangan seksual. 18

\section{Jumlah Pasangan Seksual}

Jumlah pasangan seksual memiliki hubungan yang signifikan dan merupakan faktor risiko kejadian HIV/AIDS pada wanita. Hasil analisis multivariat $p=0,003$; $\mathrm{OR}=23,321 ; 95 \% \mathrm{CI}=2,969-183,187$. Artinya wanita yang mempunyai pasangan seksual lebih dari satu memiliki risiko terjadi HIV/AIDS 23,321 kali lebih besar dibanding wanita yang punya pasangan seksual hanya1.

Salah satu jalur utama penularan HIV/AIDS adalah melalui seks yang tidak aman dengan pasangan yang terinfeksi HIV16. Baik itu heteroseksual, maupun homoseksual. ${ }^{2}$ Memiliki beberapa pasangan seksual merupakan faktor risiko tinggi dalam penularan HIV, karena semakin banyak jumlah pasangan seksual akan meningkatkan kemungkinan bahwa salah satu tindakan berhubungan seks secara acak akan mengakibatkan infeksi. ${ }^{19}$

Penelitian kohor di Zimbabwe oleh Lopman B., dkk tentang insidensi HIV selama 3 tahun yaitu tahun 2001 s/d 2003, dengan memfollow up determinan transmisi HIV yang terdekat dan mendasar.Hasil penelitian menunjukkan insidensi 19,9 per 1000 orang tahun pada pria $(95 \% \mathrm{CI}=$ 16,3- 24,2) dan 15,7 (95\% CI=13-18,9) pada wanita. ${ }^{20}$

Memiliki beberapa pasangan seksual, tetap menjadi faktor risiko yang terdekat, meskipun pasangan yang tidak sehat juga muncul sebagai faktor yang penting. ${ }^{20}$ Seperti penelitian Jewkes dkk yaitu memiliki jumlah pasangan seksual yang tinggi merup akan faktor yang berhubungan secara signifikan dengan infeksi HIV. Memiliki pasangan seksual $\geq 3$ merupakan faktor yang berhubungan dengan infeksi HIV (OR 2,39; $95 \% \mathrm{CI}=1,48-3,85) .{ }^{21}$

Hasil penelitian melalui wawancara mendalam riwayat menikah merupakan salah satu faktor risiko HIV/AIDS pada wanita, oleh karena status HIV suami sebelumnya belum diketahui oleh karena perceraian, suami meninggal terlebih dahulu, atau status HIV mantan istri dari suaminya juga tidak diketahui. Memiliki pasangan seksual lain dikarenakan melakukan hubungan seksual dengan pacar, risiko dari pekerjaan, atau riwayat pekerjaan beberapa tahun silam. 


\section{Tingkat Pendidikan}

Tingkat pendidikan rendah memiliki hubungan yang signifikan dan merupakan faktor risiko kejadian HIV/AIDS pada wanita $(p=0,049 ; \mathrm{OR}=15,011 ; 95 \%$ $\mathrm{CI}=1,011-222,772)$. Artinya wanita yang pendidikannya $\leq 9$ tahun memiliki risiko terjadi HIV/AIDS 15,011 kali lebih besar dibanding wanita yang pendidikannya $>9$ tahun.

Pendidikan adalah kunci efektif dalam merespon HIV/AIDS. Beberapa studi menunjukkan bahwa wanita yang lebih terdidik akan lebih tahu bagaimana melindungi dari infeksi HIV, menunda aktivitas seksual dan mengukurnya untuk melindungi diri sendiri. Sekolah menjadi sumber informasi yang utama tentang metode pencegahan dalam melawan HIV. Wanita yang pendidikannya $<7$ tahun akan lebih mungkin menikah pada usia 18 tahun, dan menikah lebih muda secara langsung meningkatkan risiko HIV. Anak perempuan dan wanita akan lebih rentan terinfeksi HIV jika pengetahuan tentang HIV/AIDS dan bagaimana penularannya, lebih rendah dibanding laki-laki22.

Hasil penelitian ini sejalan dengan penelitian Susilowati T., bahwa tingkat pendidikan rendah berpengaruh terhadap kejadian HIV dan AIDS dalam analisis multivariat $(p=0,001 ; \mathrm{OR}=4,709 ; 95 \% \mathrm{CI}$ : 2,117-10,474)23.

\section{Usia pertama menikah}

Usia pertama menikah memiliki hubungan yang signifikan dan merupakan faktor risiko kejadian HIV/AIDS pada wanita. Hasil analisis multivariat dengan nilai $p=0,03$; $\mathrm{OR}=5,624 ; 95 \% \mathrm{CI}=1,186$ 26,672. Artinya wanita yang usia pertama menikahnya $<20$ tahun berisiko terjadi HIV/AIDS 5,624 kali lebih besar dibanding wanita yang usia pertama menikah $\geq 20$ tahun. Interval kepercayaan (Confidence Interval) hasil analisis statistik variabel usia pertama menikah lebih sempit dibandingkan dengan variabel lain, sehingga presisinya semakin tinggi.
Beberapa penelitian menemukan bahwa risiko HIV meningkat pada wanita muda yang memiliki perbedaan usia lebih jauh antara diri mereka sendiri dengan pasangannya21.

Penelitian Kelly (2003) menunjukkan adanya hubungan HIV dengan perbedaan usia dengan pasangannya 10 tahun atau lebih pada perempuan usia 15-19 tahun $(P R R=2,04)$. Pada usia 15 tahun sebagian dari anak perempuan mulai melakukan aktifitas seksual, dan sebagian menikah pada usia 19 tahun. Pentingnya perbedaan usia dengan pasangan sebagai faktor risiko HIV meningkat pada wanita muda, terutama pernikahan di usia muda-24.

Penelitian Tiniap A. pada tahun 2012, menunjukkan mereka yang melakukan hubungan seks pertama pada usia kurang dari 20 tahun berisiko 1,36 kali (95\%CI: $0,63-$ 2,98 ) untuk terinfeksi HIV dibanding yang melakukannya pada usia 20 tahun atau lebih, meskipun hubungannya tidak signifikan 25 .

Hasil penelitian melalui wawancara mendalam mereka menikah muda oleh karena keterbatasan ekonomi dan budaya setempat. Menikah muda juga dapat memicu kekerasan dalam rumah tangga.

\section{Faktor yang tidak terbukti sebagai Faktor yang berhubungan dengan kejadian HIV/AIDS pada wanita}

Berdasarkan hasil penelitian ini, variabel yang tidak terbukti sebagai faktor yang berhubungan dengan kejadian HIV/AIDS pada wanita adalah riwayat transfusi darah, riwayat menderita penyakit menular seksual, status pengguna narkoba, kebiasaan minum alkohol, kekerasan, jenis pekerjaan, sosioekonomi, status penggunaan kondom pada pasangan, peran suami, dan peran gender tradisional.

\section{Keterbatasan Penelitian}

\section{Bias seleksi}

Peneliti sudah meminimalisir dengan mengambil responden kontrol dari Rumah 
Sakit di Kendal yang melayani VCT.

\section{Bias Informasi}

Studi kasus kontrol rawan dengan bias informasi seperti recall bias dan nonresponse bias.

Peneliti sudah mengantisipasi recall bias dengan memberikan pertanyaan terbuka disamping pertanyaan tertutup, melihat catatan medis, dan mencocokkan data di Dinas Kesehatan.

Nonresponse bias diantisipasi dengan memberikan pengertian kepada responden akan pentingnya informasi dari responden terhadap hasil penelitian dan dengan memberikan insentif sama antara kelompok kasus dan kontrol.

\section{Kesimpulan}

Variabel host yang terbukti sebagai faktor yang berhubungan dengan kejadian HIV/AIDS pada wanita adalah jumlah pasangan seksual lebih dari 1, tingkat pendidikan rendah yaitu $\leq 9$ tahun, dan usia pertama menikah $<20$ tahun.

Variabel host yang tidak terbukti sebagai faktor yang berhubungan dengan kejadian HIV/AIDS pada wanita adalah riwayat transfusi darah, riwayat menderita penyakit menular seksual, status pengguna narkoba, kebiasaan minum alkohol, kekerasan, jenis pekerjaan, dan sosioekonomi.

Variabel environment yang terbukti sebagai faktor yang berhubungan dengan kejadian HIV/AIDS pada wanita adalah riwayat HIV/AIDS pada suami. Variabel environment yang tidak terbukti sebagai faktor yang berhubungan dengan kejadian HIV/AIDS pada wanita adalah status penggunaan kondom pada pasangan, peran suami, dan peran gender tradisional.

\section{Ucapan Terimakasih}

Terimakasih kepada Dinas Kesehatan Kabupaten Kendal, RSUD Dr.Soewondo Kendal, RSI Muhammadiyah Kendal, dan RSUPDR. Kariadi yang telah berkenan memberikan izin dan membantu dalam proses pengambilan data.

\section{Daftar Pustaka}

1. Gagarina AK. 2013. HIV/AIDS. http:// www.health.am/eng/aids/index.php\#bas Accessed 31 Mei 2013

2. Locke T, Keat S, Walker A, Mackinnon R.2013. Microbiology and Infectious Diseases Move.PT Indeks.

3. Joerban Z, Djauzi A. 2009. HIV/AIDS di Indonesia. In: Sudoyo AW, Setiohadi B, Alwi I, Simadibrata M, Setiati S.eds. Buku Ajar Ilmu Penyakit Dalam. Vol 4. Jakarta: Interna Publishing.

4. WHO. Millennium Development Goals(MDGs). 2013. http://www.who. int/topics/millennium_development goals/about/en/index.html. Accessed 29Mei2013.

5. Blumenthal SJ, Ruiz MS, Dubé K, D unn - Georgiou E, Glading G. 2013. Women and HIV/AIDS.http://www. nca dv.org/HIV\%20and \%20IPV/Module $\% 2$ 0I/Handouts/Fact $\% 20$ Sheet $\% 20$ Women $\% 20$ and $\% 20$ HIV $\% 20$ AIDS--Module $\%$ 201.pdf. Accessed 6 Juni 2013.

6. WHO .2013. HIV/AIDS and Maternal, Newborn \& Child Health. 2013. http:// www.who.int $/ \mathrm{pmnch} / \mathrm{media} /$ pressmateri als/fs/fs hivaids mnch/en/.
Accessed
15
Mei
2013.

7. UNAIDS.2013.Global Report:UNAIDS Report on The Global AIDS Epidemic 2013. http://www.unaids.org/en/media/ unaids/contentassets/documents/epidemiology/2013/gr2013/UNAIDS_Glo bal Report 2013 en.pdf. Accessed15 Oktober, 2014.

8. WHO. World Health Statistic 2013. http://apps.who.int/iris/bitstream/10665 $/ 81965 / 1 / 9789241564588$ eng.pdf?ua $=$ 1. Accessed 28 Juni 2013.

9. Komisi Penanggulangan AIDS Nasio nal. 2010. Strategi dan Rencana Aksi Nasional Penanggulangan HIV dan AIDS Tahun 2010- 2014. Jakarta:Komisi Penanggulangan AIDS Nasional;

10. Kemenkes RI . 2014. Statistik Kasus HIV/ 
AIDS di Indonesia dilapor s/d Juni 2014 http://spiritia.or.id/Stats/Stat Curr.xls. Accessed 5 Oktober 2014.

11. Komisi Penanggulangan AIDS Provinsi Jateng. 2014. Kondisi HIV\& AIDS di Jawa Tengah 1993 s/d 30 Juni 2014. http://www.aidsjateng.or.id/data/Data\% 20HIV\%20dan \%20AIDS\%20Prov. $\% 2$ 0Jateng\%20per\%20Juni\%202014.ppt. Accessed 14 Oktober 2014.

12. Dinas Kesehatan Kabupaten Kendal. 2014. Data Kasus HIV/AIDS di Kabupaten Kendal periode Tahun 2000-2014 (Juli);2014.

13. Dinas Kesehatan Kabupaten Kendal. 2014. Profil Kesehatan Kabupaten Kendal Tahun 2012.

14. Natsir LM. 2014. Menjembatani Kesenjangan Informasi Kesehatan Reproduksi.

15. Hapsari H, Setiawan W.2014. Pantura Paling Rawan HIV/AIDS http://www. koran- sindo.com/read/930821/151/ pantura-paling-rawan-hiv-aids.

Accessed 1 Desember, 2014.

16. Pinsky L, Douglas PH. 2009. The Columbia University Handbook on HIV/AIDS. Coloumbia: Columbia University. http://health.columbia. edu/files/healthservices/pdf/GHAPHIV Aids_Handbook.pdf. Accessed 8 Juni 2013.

17. Kemenkes_RI. 2014. Total Football Tanggulangi HIV/AIDS.http://www. kemkes.go.id/downloads/advertorial- d e wi/3\%20Adv HIV-AIDS.pdf. Accessed 24 Maret 2014.

18. Green CW. 2005. HIV, Pregnancy and Woman Health: Yayasan.
19. Muchimba M, Haberstick BC, Corley RP, McQueen MB. Frequency of Alcohol Use in Adolescence as a Marker for Subsequent Sexual Risk Behavior in Adulthood. Journal of AdolescentHealth.2013;53(2):215-221

20. Lopman B, Nyamukapa C, Mushati P, et al. HIV incidence in 3 years of follow-up of a Zimbabwe cohort-1998-2000 to 2001-03: Contributions of proximate and underlying determinants to transmission. International Journal of Epidemiology 2008.

Jewkes R, Dunkle K, Nduna M, et al.

21. Factors associated with HIV sero-status in young rural South African women: connections between intimate partner violence and HIV. International Journal of Epidemiology 2006(35):1461-1468. UNAIDS, UNFPA, UNIFEM. 2013.

22. Woman and HIV/AIDS: Confronting the Crisis. http://www.unfpa.org/upload/ lib_pub_file/308_filename_women aids1.p̄̄f. Accessed 3 Januari 2013.

23. Susilowati T. 2003.Faktor-Faktor Risiko yang Berpengaruh terhadap Kejadian HIV dan AIDS (Studi Kasus di RSUP Dr. Kariadi Semarang). Jurnal Komunikasi Kesehatan;2(1).

24. Kelly RJ, Gray RH, Sewankambo NK, et al. 2003. Age Differences in Sexual Partners and Risk of HIV-1 Infection in Rural Uganda. Journal of Acquired Immune Deficiency Syndromes (J AIDS);32.pp.446-451.

25. Tiniap A. 2012. Hubungan antara Usia Pertama Kali Berhubungan Seks dengan Risiko Terinfeksi HIV Pada Klien Klinik VCT RSUD Kabupaten Manokwari Provinsi Papua Barat. Jakarta:Universitas Indonesia. 